\title{
TINJAUAN TERHADAP DOKTRIN KOVENAN KERJA DALAM TEOLOGI REFORMED
}

\author{
Ranjawali N. Matalu \\ Mimbar Reformed Injili Indonesia Sunter
}

\begin{abstract}
ABSTRAK: Dalam artikel ini, pertama-tama penulis membahas asal mula doktrin kovenan kerja, yang menurut hemat penulis, terutama dimulai pada zaman reformasi. Di dalamnya, penulis menyimpulkan bahwa doktrin ini dipelopori oleh Bullinger dan Calvin. Akan tetapi, dalam perkembangannya di kemudian hari, muncul perbedaan pandangan di antara para teolog Reformed mengenai apakah doktrin kovenan kerja diajarkan dalam Kitab Suci atau tidak. Karena itu, dalam bagian berikutnya, penulis mencoba menganalisis argumenargumen yang dikemukakan penentang doktrin kovenan kerja. Dari analisis ini, penulis menyimpulkan bahwa argumen-argumen yang mereka kemukakan tidak selaras dengan ajaran Alkitab. Kesimpulan ini membawa kita untuk melihat lebih lanjut implikasi doktrinal yang ada ketika kita menerima doktrin kovenan kerja. Dalam artikel ini, penulis membahas dua implikasi doktrinal, yaitu doktrin transmisi dosa dan ketidakberdosaan Kristus.
\end{abstract}

KATA KUNCI: Kovenan kerja, Bullinger, Calvin, hukum-anugerah, sumpah kovenan, penebusan, transmisi dosa, ketidakberdosaan Kristus. 
ABSTRACT: In this article, the writer deals with the origin of covenant of works doctrine which, according to the writer, was started at the Reformation era. The writer believes that this doctrine is originated by Bullinger and Calvin. However, in its development, there are dissenting views within Reformed Theologians on whether the covenant of works doctrine is taught in the scripture. Therefore, the writer then analyzes the arguments given by those who disagree with the doctrine of covenant of works. From the analysis, the writer concludes that their given arguments are not in line with the teaching of the scripture. This conclusion brought us to see the further doctrinal implication that entails when we receive the doctrine of covenant of works. In this article, the writer deals with two doctrinal implications, the transmission of sin and the sinlessness of Christ.

KEYWORDS: Covenant of works, Bullinger, Calvin, law-grace, covenant oath, redemption, sin transmission, sinlessness of Christ.

\section{Pendahuluan}

Salah satu keunikan teologi Reformed adalah pengajarannya mengenai kovenan. Melalui doktrin kovenan, teologi Reformed dapat merangkum seluruh kisah sejarah penebusan dari titik alfa sampai dengan titik omega. Dalam kovenan kerja (covenant of works), semua manusia, berdosa di dalam Adam; dalam kovenan anugerah (covenant of grace), umat pilihan dibenarkan di dalam Kristus. Dalam penilaian Herman Bavinck, adalah hal yang begitu penting untuk 
mempertahankan kedua kovenan ini secara bersama-sama. Itu sebabnya, dalam Reformed Dogmatic yang ia tulis, ia mengatakan lebih dari sekali bahwa kovenan kerja dan kovenan anugerah berdiri atau jatuh bersama-sama. ${ }^{1}$ Sedangkan John Murray, meskipun ia sendiri tidak menerima the Adamic Administration sebagai kovenan, mengakui betapa pentingnya kedudukan dua kepala kovenan. Dengan kata-kata yang mengesankan, ia menulis demikian, "They [Adam and Christ] stand in unique relations to mankind. There is none before Adam - he is the first man. There is none between - Christ is the second man. There is none after Christ - he is the last Adam (1Corinthians 15:44-49)."2

Akan tetapi, terjadi perbedaan pandangan di antara para teolog Reformed mengenai apakah doktrin kovenan kerja ada dalam Kitab Suci atau tidak. Teolog-teolog Reformed seperti Charles Hodge (17971878), Bavinck (1854-1921), dan Louis Berkhof (1873-1957), menerima adanya doktrin kovenan kerja dalam Kitab Suci. Sedangkan teologteolog Reformed seperti Murray (1898-1975), G.C. Berkouwer (19031996), dan Anthony Hoekema (1913-1988) menolak doktrin kovenan kerja.

Melihat perbedaan pandangan di antara para teolog Reformed di atas, maka dalam artikel ini, penulis akan mencoba meninjau argumen-argumen yang dikemukakan oleh penentang doktrin

\footnotetext{
1 Anthony Hoekema, Created in God's Image (Grand Rapids: Eerdmans, 1986), 118.

2 John Murray, "The Adamic Administration," Collected Writings of John Murray 2: Systematic Theology (Edinburgh: Banner of Truth Trust, 1977), 49.
} 
kovenan kerja berdasarkan sudut pandang pendukung doktrin kovenan kerja. Tetapi sebelum itu, penulis akan membahas terlebih dahulu secara singkat perkembangan doktrin kovenan kerja dalam sejarah, khususnya pada zaman reformasi. Hal ini dimaksudkan agar kita memiliki pemahaman yang lebih komprehensif mengenai doktrin kovenan kerja di dalam sejarah teologi Reformed. Terakhir, penulis akan membahas implikasi doktrinal ketika kita menerima doktrin kovenan kerja.

\section{Perkembangan Doktrin Kovenan Kerja}

Dalam sejarah teologi, benih doktrin kovenan kerja sudah muncul dalam karya Heinrich Bullinger (1504-1575) yang berjudul Compendium of the Christian Religion (1556). ${ }^{3}$ Sebetulnya, lebih dari dua dekade sebelumnya, Bullinger sudah menghasilkan satu karya penting yang membahas kovenan dengan lebih komprehensif, yaitu The Covenant (1534). Tetapi karya ini tidak secara khusus membahas doktrin kovenan kerja. Charles S. McCoy dan J. Wayne Baker mengatakan bahwa The Covenant menyediakan sumber yang sangat penting bagi federalisme, yang mana di dalamnya ia menjelaskan bahwa kovenan yang pertama adalah kovenan dengan Adam. ${ }^{4}$ Munculnya karya ini memang tidak terlepas dari polemik yang terjadi dengan kaum Anabaptis terkait definisi gereja, negara, disiplin

\footnotetext{
3 Louis Berkhof, Systematic Theology (Grand Rapids: Eerdmans, 2008), 211.

4 Charles S. McCoy dan J. Wayne Baker, Fountainhead of Federalism: Heinrich Bullinger and the Covenant Tradition (Louisville: Westminster, 1991), 20.
} 
Kristen, dan masalah pemerintahan. ${ }^{5}$ Geerhardus Vos menambahkan bahwa masalah baptisan bayi, yang merupakan salah satu sumber konflik dengan Anabaptis, ikut menyebabkan perkembangan konsep kovenan di Swiss. ${ }^{6}$ Meskipun demikian, McCoy dan Baker mengatakan bahwa sebetulnya karya ini bukan semata-mata sebagai respon terhadap polemik tersebut, karena sembilan tahun sebelumnya, Bullinger telah mengembangkan konsep kovenan dan mengaplikasikannya dalam berbagai situasi. ${ }^{7}$

Berdasarkan analisis McCoy dan Baker, dalam karya yang menyediakan sumber yang sangat penting bagi federalisme ini, Bullinger melihat kovenan sebagai "the divine framework for human life, both religious and civil, from the beginning of the world until the last judgment." ${ }^{\prime}$ Lebih lanjut McCoy dan Baker mengatakan bahwa bagi Bullinger, "Christianity had begun with Adam when the covenant had first been made with humans." 9

Setelah menjelaskan tiga cara berbeda yang muncul untuk mengekspresikan doktrin Protestan tentang keselamatan melalui anugerah, yaitu: (1) pembedaan Taurat-Injil yang dilakukan Martin Luther (1483-1546), yang disertai penekanannya pada perbudakan kehendak dan kebenaran pasif; (2) predestinasi ganda dan pemilihan

\footnotetext{
5 Ibid., 18-9.

6 Geerhardus Vos, "The Doctrine of the Covenant in Reformed Theology," Redemptive History and Biblical Interpretation, ed. Richard B. Gaffin, Jr. (Phillipsburg: P \& R, 1980), 236.

7 McCoy dan Baker, Fountainhead, 18-9.

8 Ibid., 20.

9 Ibid.
} 
(election) yang diajarkan John Calvin (1509-1564), yang secara hatihati memproteksi sola fide dan sola gratia dan cenderung menghindari konsep kovenan bilateral; dan (3) pola federal dari Bullinger, dengan ide tentang suatu kovenan bilateral sebagai sarana yang melaluinya Allah bekerja dengan manusia dalam sejarah, McCoy dan Baker menyimpulkan bahwa di antara ketiganya, Bullinger adalah satusatunya teolog yang dapat secara tepat disebut sebagai teolog federal. ${ }^{10}$

Akan tetapi, tidak berarti bahwa konsep kovenan sama sekali tidak ditemukan dalam pemikiran Calvin. Memang Vos mengatakan, "In Calvin, too, mention is frequently made of the covenants. However, his theology was built on the basis of the Trinity, and therefore the covenant concept could not arise as a dominant principle in his case."11 Tetapi Peter A. Lillback melihat Calvin dari sisi yang berbeda ketika ia mengatakan, "The frequency with which Calvin uses the Latin terms for Covenant in the Institutes indicates that he considers the idea to be significant."12 Lillback kemudian memperlihatkan survei yang dilakukan Ford Lewis Battles dalam Concordance to Calvin's Corpus Reformatorum Edition of the Institutes of 1559 terkait kemunculan istilah-istilah Latin yang menunjuk kepada kovenan. Istilah "pactum"

\footnotetext{
10 Ibid., 20.

11 Vos, 236. Dalam "The Doctrine of the Covenant in Reformed Theology", Vos sama sekali tidak memberikan alasan mengapa ia berkesimpulan bahwa teologi Calvin dibangun berdasarkan konsep Tritunggal. Ada dua kemungkinan untuk hal ini: (1) kesimpulan ini adalah hasil penelitian Vos sendiri, atau (2) kesimpulan ini ia kutip dari sarjana lain.

12 Peter A. Lillback, The Binding of God: Calvin's Role in the Development of Covenant Theology (Grand Rapids: Baker Academic, 2001), 126.
} 
dan istilah-istilah yang bertalian, yaitu "paciscor" dan "pactio" muncul 35 kali; istilah "foedus" dan istilah lain yang bertalian, muncul 154 kali; istilah "testamentum" muncul 84 kali. Jadi semuanya ada 273 istilah Latin untuk kovenan dalam Institutes. ${ }^{13}$ Sebagai perbandingan, Calvin memakai istilah "Trinitatis" hanya 26 kali dalam seluruh Institutes. ${ }^{14}$ Bagi Lillback, hal ini penting karena sebagian besar sarjana percaya bahwa divisi dalam Institutes ditentukan oleh konsep Calvin mengenai Tritunggal. ${ }^{15}$

Lillback juga menunjukkan bahwa survei ini semakin menarik bila melihat pendistribusian istilah "pactum", "foedus", dan "testamentum" dalam setiap divisi Insitutes. Dalam Buku Satu muncul 11 kali, dalam Buku Dua muncul 86 kali, dalam Buku Tiga muncul 47 kali, dan dalam Buku Empat muncul 129 kali. ${ }^{16}$ Bagi Lillback, adalah hal yang wajar jikalau istilah-istilah tersebut lebih banyak muncul dalam Buku Dua dan Empat karena dalam bagian itu Calvin sedang membahas kesatuan dan keberagaman Perjanjian Lama dan Baru, dan doktrin mengenai sakramen dan baptisan bayi. Demikian juga dengan Buku Tiga, karena di dalamnya Calvin sedang membahas pengudusan, pembenaran, dan predestinasi. Ide kovenan perlu dipakai untuk menjelaskan doktrin-doktrin tersebut. Yang menarik

\footnotetext{
13 Lillback, Binding of God, 126. Lillback mengatakan bahwa jumlah ini belum termasuk istilahistilah yang bersinonim dengan ide kovenan, seperti "obstringes", "vinculo", "conjunctionis", dan "adoptio". Tetapi istilah-istilah ini tidak selalu dipakai dalam pengertian kovenan.

14 Ibid., 127

15 Ibid.

16 Ibid., 127.
} 
adalah kemunculan istilah-istilah tersebut dalam Buku Satu. Dalam bagian ini, Calvin sebetulnya sedang berbicara mengenai doktrin Allah dan bukan membahas doktrin keselamatan. Meskipun demikian, istilah "kovenan" tetap muncul 11 kali. ${ }^{17}$ Itu sebabnya, Lillback akhirnya menyimpulkan bahwa "the covenant appears to be an integral part of Calvin's theology."18

Dalam tulisannya yang lain, Lillback menunjukkan bahwa sarjana-sarjana seperti Leonard J. Trinterud, Baker, McCoy, dan Joseph C. McLelland mengakui bahwa Calvin menggunakan gagasan kovenan, meskipun dari sudut pandang mereka, penggunaan Calvin akan kovenan berbeda dengan teolog-teolog Rhineland seperti Bullinger dan Johannes Oecolampadius (1482-1531). ${ }^{19}$ Dalam analisis Lyle D. Bierma misalnya, Trinterud mengemukakan tiga perbedaan penting antara konsep kovenan Calvin dengan para reformator Zurich dan Rhineland, yaitu:

\footnotetext{
17 Ibid.

18 Ibid.

19 Peter A. Lillback, "Penafsiran Calvin atas Sejarah Keselamatan: Kontinuitas dan Diskontinuitas Kovenan" dalam Penuntun ke dalam Teologi Institutes Calvin, ed. David W. Hall dan Peter A. Lillback, terj. Lanna Wahyuni (Surabaya: Momentum, 2009), 189-90.
} 
Calvin

1) The covenant is unilateral: God's unconditional promise.

2) The burden of fulfilling the covenant rests on God.

3) The covenant is fulfilled in the incarnation, death, and resurrection of Jesus Christ.

\section{Zurich/Rhineland Reformers}

1) The covenant is bilateral: God's conditional promise and the response of the human partner.

2) The burden of fulfilling the covenant rests on the human partner.

3) The covenant is fulfilled in the obedience of the human partner and God's reciprocal reward 20

Menurut penulis, hal penting yang ditemukan dalam penyelidikan para sarjana di atas adalah, mereka sepakat untuk menyimpulkan bahwa Calvin menggunakan gagasan kovenan secara luas dalam tulisan-tulisannya. Perihal apakah konsep kovenan Calvin di satu sisi, dengan Oecolampadius dan Bullinger di sisi yang lain, berbeda atau tidak, itu adalah masalah lain. Bagi penulis, poin penting yang lebih perlu untuk diketahui adalah, apakah Calvin juga mengajarkan doktrin kovenan kerja atau tidak. Ketika menjawab pertanyaan ini, pertama-tama Lillback memperlihatkan penyelidikan Donald J. Bruggink yang menyimpulkan bahwa bentuk teologi kovenan merusak teologi Calvin dengan memasukkan kovenan kerja sebagai suatu hubungan yang sah antara manusia dan Allah, dan kemudian membawa kerja ke dalam kovenan anugerah. ${ }^{21}$ Demikian juga dengan penyelidikan Hoekema dan Elton M. Eenigenburg yang

20 Lyle D. Bierma, “Federal Theology in the Sixteenth Century: Two Traditions?,” Westminster Theological Journal 45, no. 2 (1983): 305.

21 Lillback, Penafsiran Calvin, 189. 
membatasi pemikiran kovenantal Calvin hanya pada kovenan anugerah dan mengesampingkan kovenan kerja dan kovenan penebusan.22 Penulis sendiri menemukan bahwa dalam artikelnya yang berjudul The Covenant of Grace in Calvin's Teaching, Hoekema menyimpulkan bahwa Calvin tidak mengajarkan doktrin kovenan kerja. Menurutnya, doktrin ini adalah perkembangan yang terjadi belakangan di dalam teologi federal. ${ }^{23}$

Namun demikian, dalam penelitiannya sendiri, Lillback menemukan bahwa konsep kovenan kerja ditemukan dalam tulisantulisan Calvin, meskipun secara istilah tidak ada. Lillback memberikan enam argumen untuk membuktikan keberadaan konsep kovenan kerja dalam teologi Calvin. Pertama, Augustinus mengajarkan konsep kovenan prelapsarian. Mempertimbangkan pemakaian Calvin yang sangat banyak akan pemikiran Augustinus secara umum, dan dalam konteks kovenan secara khusus, sangat mungkin Augustinus telah mempengaruhi Calvin dalam hal kovenan prelapsarian. Kedua, adalah signifikan bahwa Calvin menunda diskusi tentang kovenan anugerah sampai dengan Buku Dua Institutes karena diskusi dalam Buku Satu dibatasi pada pengetahuan tentang Allah Pencipta. Pendekatan ini menyediakan struktur bagi suatu perbedaan antara kovenan postlapsarian dan suatu kemungkinan kovenan prelapsarian. ${ }^{24}$ Ketiga, Calvin memunculkan satu masalah,

\footnotetext{
22 Ibid., 196.

23 Anthony A. Hoekema, Calvin Theological Journal 2 (1967): 133.

24 Lillback, Binding of God, 287.
} 
yang mana solusi sempurna dari masalah tersebut hanya ditemukan dalam kovenan kerja. Misalnya, ia menggambarkan Adam berada dalam periode tanpa dosa yang bersifat sementara, “... the image of God was only shadowed forth in man till he should arrive at his perfection." 25 Ia juga menulis, "The state of man was not perfected in the person of Adam ..." dan "before the fall of Adam, man's life was only earthly, seeing it had no firm and settled constancy." 26 Keempat, Adam berada di bawah hukum, yang kalau dipelihara dengan setia akan memimpinnya kepada hidup yang lebih baik tanpa kematian. Calvin menuliskan demikian:

We now understand what is meant by abstaining from the tree of the knowledge of good and evil; namely, that Adam might not, in attempting one thing or another, rely upon his own prudence; but that, cleaving to God alone, he might become wise only by his obedience. ${ }^{27}$

Kelima, penafsirannya tentang imago dei dalam hubungannya dengan hukum alam dan hati nurani. Calvin mengajarkan bahwa hati nurani adalah bagian dari imago dei yang dimiliki bersama hukum alam, yang mana identik dengan sepuluh hukum. Jadi konsep Calvin tentang hubungan legal pra-kejatuhan bukan hanya larangan tunggal dari Allah kepada Adam, tetapi terjalin bersama hukum moral juga. Karena Adam akan mendapatkan hidup kekal melalui ketaatan, ini menyiratkan bahwa ketaatan yang penuh kepada hukum moral dan

\footnotetext{
25 Comm. ad Genesis 1:26, 2:7.

26 Ibid.

27 Comm. ad Genesis 2:9.
} 
ketentuan-ketentuan lainnya menjadikan Adam menerima "settled constancy". Keenam, argumen terakhir Calvin adalah adanya sakramen. Calvin mengatakan,

He gave the tree of life its name, not because it could confer on man that life with which he had been previously endued, but in order that it might be a symbol and memorial of the life which he had received from God. For we know it to be by no means unusual that God should give to us the attestation of his grace by external symbols. He does not indeed transfer his power into outward signs; but by them he stretches out his hand to us, because, without assistance, we cannot ascend to him. ${ }^{28}$

Hal yang dapat disimpulkan di sini adalah bahwa penulis setuju dengan McCoy dan Baker yang menyatakan bahwa Bullinger adalah teolog kovenan yang mengajarkan doktrin kovenan kerja. Penulis juga setuju dengan Lillback yang menyatakan bahwa Calvin adalah teolog kovenan yang mengajarkan doktrin kovenan kerja. Adalah benar jikalau dikatakan bahwa Bullinger merupakan perintis teologi kovenan, sepanjang yang dijadikan acuan adalah diterbitkannya The Covenant dua tahun sebelum Institutes edisi pertama (1536) dan tafsiran Calvin atas Kitab Kejadian yang baru ditulis tahun 1554. Lillback sendiri melihat adanya kesesuaian antara pemikiran Bullinger dan Calvin mengenai kovenan. Calvin bersimpati dengan Bullinger yang memulai sejarah kovenan dengan Adam. Sikap simpati ini dibuktikan ketika Calvin mendaftarkan pihak-pihak yang terlibat dalam kovenan, yang mana Calvin memulainya dengan 
Adam. ${ }^{29}$

Sebelum mengakhiri bagian ini, satu hal yang patut disebutkan adalah bahwa pada tahun 1647, melalui usaha keras para teolog Puritan, doktrin kovenan kerja mendapatkan status kredo. Doktrin ini diformulasikan secara resmi dalam Westminster Confession of Faith. Di dalamnya dinyatakan:

The distance between God and the creature is so great, that although reasonable creatures do owe obedience unto him as their Creator, yet they could never have any fruition of him as their blessedness and reward, but by some voluntary condescension on God's part, which he hath been pleased to express by way of covenant. The first covenant made with man was a covenant of works, wherein life was promised to Adam, and in him posterity, upon condition of perfect and personal obedience..$^{30}$

\section{Perbedaan Pandangan Terkait Doktrin Kovenan Kerja}

Dalam perkembangannya di kemudian hari, muncul keberatan dari Murray, Berkouwer, dan Hoekema terhadap doktrin kovenan kerja. Jikalau disimpulkan, keberatan-keberatan mereka mencakup empat hal: (1) menyebut pengaturan Adamik sebagai kovenan berarti kurang memerhatikan unsur-unsur anugerah yang ada di dalamnya, (2) Alkitab tidak menyebut pengaturan ini sebagai kovenan, (3) tidak ada indikasi dalam pasal-pasal awal kitab Kejadian mengenai sumpah kovenan dan upacara pengesahannya, dan (4) kovenan dalam Alkitab selalu dipakai dalam konteks penebusan. Karena itu,

\footnotetext{
29 Lillback, Binding of God, 142.

30 Westminster Confession of Faith (Glasgow: Free Presbyterian, 1985), 41-2.
} 
dalam bagian ini, pembahasan penulis akan mengacu kepada uruturutan empat poin keberatan mereka.

\section{Kovenan Kerja dan Elemen Anugerah}

Murray mengajukan dua alasan untuk menolak penyebutan istilah "kovenan kerja", yaitu:

(1) The term is not felicitous, for the reason that the elements of grace entering into the administration are not properly provided for by the term 'works'. (2) It is not designated a covenant in Scripture. Hosea 6:7 may be interpreted otherwise and does not provide the basis for such a construction of the Adamic economy. Besides, Scripture always uses the term covenant, when applied to God's administration to men, in reference to a provision that is redemptive or closely related to redemptive design. Covenant in Scripture denotes the oath-bound confirmation of promise and involves a security which the Adamic economy did not bestow. ${ }^{31}$

Karena itu, ia memilih untuk menggunakan istilah "pengaturan Adamik" (the Adamic Administration) daripada "kovenan kerja" untuk mendeskripsikan relasi Tuhan Allah dengan Adam sebelum kejatuhan. Menariknya, meskipun ia menolak pemakaian istilah "kovenan kerja", tetapi elemen-elemen dalam pengaturan Adamik yang ia paparkan, sama dengan yang dinyatakan pengusung doktrin kovenan kerja: Adam disebut sebagai kepala ras manusia; syaratnya adalah ketaatan; janjinya adalah hidup; dan ancaman hukumannya

\footnotetext{
31 Murray, Collected Writings, 49. Meskipun di sini penulis sedang membahas pengabaian elemen anugerah dalam kovenan kerja, penulis tetap memasukkan semua keberatan Murray karena penjelasannya cukup singkat.
} 
adalah kematian. ${ }^{32}$ Karena kesamaan ini, seringkali disimpulkan bahwa Murray hanya menolak istilah, dan bukan menolak isi doktrin kovenan kerja. Akan tetapi, dalam kajian penulis, penolakan terhadap istilah "kovenan kerja" menjadikan elemen-elemen di dalamnya mengandung masalah. Misalnya, ia menyebut Adam sebagai kepala ras manusia. Bagi penulis, Adam secara sah disebut sebagai kepala ras manusia hanya jikalau ia ditempatkan dalam konteks kovenan. Jika tidak, maka Adam hanya bisa disebut sebagai nenek moyang ras manusia. Dengan demikian, jikalau Adam disebut sebagai kepala ras manusia, maka pemakaian istilah "kovenan" merupakan suatu keharusan.

Sedangkan Berkouwer, setelah menunjukkan pandangan Schippers yang menyetujui adanya hukum di dalam status prolapsarian manusia dan bahwa hukum itu terpisah dari Injil, ia mengatakan, "Man's original life under God's rule cannot be regarded, for even a moment, apart from God's love and communion." 33 Lebih lanjut ia mengatakan, karena komuni itu, perintah Allah tidak pernah impersonal atau hanya merupakan suatu tatanan hukum. Setiap diskusi mengenai usus legis, dalam berbagai dimensinya, hanya dapat dipahami dalam pengertian kebaikan mutlak dari perintah-perintah

\footnotetext{
32 Murray, Collected Writings, 50-6. Keberatan bahwa kovenan selalu merujuk kepada penebusan akan dibahas dalam "Kovenan Kerja dan Konteks Penebusan", sedangkan keberatan bahwa kovenan dikonfirmasi dengan ikatan sumpah akan dibahas dalam "Kovenan Kerja dan Sumpah Kovenan".

33 G.C. Berkouwer, Studies in Dogmatics: Sin (Grand Rapids: Eerdmans, 1971), 206.
} 
Allah bagi manusia ciptaan. ${ }^{34}$ Berdasarkan semua ini, ia menekankan bahwa kita jangan pernah menafsirkan adanya antitesis antara kovenan kerja dan kovenan anugerah. Ia mengatakan:

We err if we interpret this distinction as though God's original covenant had to do with our work or our achievement or our fulfillment of his law, while the later covenant of grace has reference to the pure gift of his mercy apart from all our works. If we assume this we are compelled to say that God's original relation to man was strictly "legal," or that the structure of that relation was determined by man's merit. ${ }^{35}$

Untuk memperkuat pandangannya, ia menggandeng De Graaf dan mengatakan bahwa De Graaf telah menolak konsep kovenan kerja dan telah mengatakan bahwa hal itu lebih banyak mengundang masalah dibanding apa yang mungkin diselesaikannya. ${ }^{36}$ Dalam hal ini, boleh dikatakan bahwa Berkouwer menolak doktrin kovenan kerja karena menganggap tidak ada perbedaan pola relasi antara Tuhan Allah dengan Adam, sebelum dan sesudah kejatuhan, sebagaimana diindikasikan oleh istilah "kerja" dan "anugerah". Dan jikalau dikaji lebih dalam, ternyata konsep semacam ini adalah warisan dari Karl Barth (1886-1968). Barth sendiri menolak historisitas kisah penciptaan dan kejatuhan Adam dan menyebutnya sebagai saga. ${ }^{37}$

\footnotetext{
$34 \quad$ Ibid., 206-7.

35 Ibid., 207.

36 Ibid.

37 Karl Barth, Church Dogmatics: The Doctrine of Reconciliation, jilid IV/1 (Edinburgh: T \& T Clark, 2004), 508.
} 
Ketika mengemukakan pandangannya mengenai hal ini, Cornelis Venema mengatakan bahwa kelemahan utama dari teologi Barth dan penerusnya adalah, mereka tidak menyediakan tempat bagi wahyu biblikal tentang sejarah penciptaan, kejatuhan, dan penebusan. Perbedaan antara keadaan manusia di hadapan Allah sebelum dan sesudah kejatuhan dihapuskan. ${ }^{38}$ Karena itu, mereka keberatan ketika pengusung kovenan kerja mengajarkan kovenan pra-kejatuhan, dan membedakannya dengan kovenan pascakejatuhan. Padahal semua ini menggemakan struktur dasar kisah Alkitab mengenai penciptaan, kejatuhan, dan penebusan. ${ }^{39}$ Sedangkan J. Mark Beach, dalam tulisannya terkait keberadaan konsep kovenan kerja dalam Tiga Pasal Keesaan Gereja Reformed Belanda, menjelaskan bahwa keberatan ini didasarkan pada dikotomi yang salah, pilihan yang either/or antara hukum dan anugerah yang sebetulnya tidak bertentangan. Pernyataan positif doktrin kovenan kerja menegaskan bahwa kasih dan persekutuan dengan Allah adalah hubungan yang riil dan tepat, yang ada antara Allah dan pembawa gambar-Nya di Firdaus sebelum kejatuhan..$^{40}$

Sementara itu, ketika menolak doktrin kovenan kerja karena mengabaikan elemen anugerah, Hoekema mengajukan argumen yang mirip dengan Murray. Ia mengatakan bahwa menyebut

\footnotetext{
38 Cornelis P. Venema, "Recent Criticisms of the 'Covenant of Works' in the Westminster Confession of Faith," Mid-America Journal of Theology 9, no. 2 (1993): 187.

39 Ibid., 187.

40 J. Mark Beach, "Some Observations About the Three Forms of Unity and the Doctrine of the Covenant of Works," Mid-America Journal of Theology no. 21 (2010): 116.
} 
pengaturan Adamik sebagai kovenan kerja berarti kurang memerhatikan unsur-unsur anugerah yang ada di dalamnya. Karena, meski benar bahwa Adam dan Hawa menerima berkat berupa hidup terus-menerus di dalam persekutuan dengan Allah di sepanjang jalur "kerja" (yaitu dengan ketaatan sempurna kepada perintah Allah), tidak berarti ketaatan ini melayakkan mereka untuk mendapatkan pahala yang oleh banyak pihak dipandang meliputi hidup kekal. Allah berhak menerima ketaatan yang sempurna dari manusiamanusia ciptaan-Nya; tetapi, Ia tidak wajib memberikan imbalan bagi ketaatan mereka. Bahwa Allah berjanji untuk memberikan pahala seperti itu (sebagai implikasinya), itu harus dipahami sebagai karunia dari anugerah Allah. ${ }^{41}$

Jikalau keberatan Hoekema di atas sudah dirumuskan dengan tepat, maka menurut penulis, ada dua hal yang perlu dikritisi dari pernyataannya. Pertama, di satu sisi ia setuju bahwa Adam dan Hawa menerima hidup kekal melalui ketaatan sempurna. Tetapi di sisi yang lain, ia mengatakan bahwa Adam dan Hawa wajib taat kepada Allah dan ketaatan ini tidak melayakkan mereka untuk mendapatkan hidup kekal, karena hidup kekal adalah anugerah Allah. Dalam kajian penulis, dua pernyataan ini saling berkontradiksi dan kontradiksi ini disebabkan keengganan Hoekema untuk menerima pembedaan yang dilakukan Berkhof terkait dua macam relasi antara Tuhan Allah dengan Adam. Berkhof menjelaskan dua macam relasi antara Tuhan Allah dengan Adam sebelum kejatuhan, yaitu relasi

41 Hoekema, Created, 119. 
alamiah dan relasi kovenan. Dalam relasi alamiah, sebagai ciptaan Allah, Adam secara alamiah berada di bawah hukum dan tugasnya adalah menaati hukum yang Allah berikan. Ketaatan kepada hukum tidak memberikan hak kepadanya untuk menuntut pahala sedangkan pelanggaran kepada hukum akan membawanya kepada penghukuman. Sedangkan dalam relasi kovenan, Adam bertindak sebagai kepala mewakili semua manusia keturunannya. Ketaatan kepada hukum menjadikan Adam berhak untuk mengklaim upah hidup kekal bagi dirinya sendiri dan bagi keturunannya. Sedangkan ketidaktaatan terhadap hukum tetap menjadikan ia dan keturunannya mendapatkan penghukuman. ${ }^{42}$ Jikalau Hoekema menerima pembedaan seperti ini, maka sebetulnya pernyataannya tidak akan berkontradiksi. Ketika ia mengatakan bahwa ketaatan Adam dan Hawa tidak menjadikan mereka memiliki hak untuk mendapatkan pahala, adalah benar dalam konteks relasi alamiah. Ketika ia setuju bahwa Adam dan Hawa menerima hidup kekal melalui ketaatan sempurna, juga benar dalam konteks relasi kovenan.

Kedua, Hoekema mengatakan bahwa penyebutan pengaturan Adamik sebagai kovenan kerja menunjukkan kurangnya perhatian terhadap unsur-unsur anugerah yang ada di dalamnya. Ketika menjawab keberatan ini, Muriwali Yanto Matalu mengatakan bahwa ketika pengusung doktrin kovenan kerja menyatakan bahwa perintah tersebut adalah sebuah kovenan kerja yang menekankan ketaatan Adam, tidak berarti pendukung kovenan kerja mengatakan bahwa

42 Berkhof, Systematic, 215. 
anugerah Tuhan tidak terkandung di dalamnya..33 Matalu kemudian memberikan perbandingan antara doktrin kovenan kerja dengan perintah Taurat dalam Perjanjian Lama. Dalam perintah Taurat juga ada unsur-unsur anugerah. Hal ini dapat dilihat dalam poin berikut: (1) Melalui Taurat, orang Israel dibawa kepada satu pemahaman akan ketidakmampuan mereka, sehingga membangkitkan pengharapan mereka akan Mesias yang akan datang. (2) Dalam setiap pelanggaran terhadap hukum Taurat, kecuali yang langsung berkaitan dengan hukuman mati, Tuhan menyediakan sarana penebusan dosa untuk sementara waktu melalui darah hewan yang dikorbankan yang melambangkan penebusan yang bersifat sempurna yang diadakan oleh Kristus yang akan datang. ${ }^{44}$ Menurut penulis, meskipun perbandingan yang dikemukakan Matalu bukanlah perbandingan yang simetris, karena hukum Taurat diberikan sesudah kejatuhan sedangkan kovenan kerja berlangsung sebelum kejatuhan, tetapi paling tidak dalam hal ini hukum Taurat telah memberikan gambaran kepada kita bahwa dalam relasi Tuhan Allah dengan manusia, elemen anugerah tidak pernah diabaikan.

\footnotetext{
43 Muriwali Yanto Matalu, Dogmatika Kristen: Dari Perspektif Reformed (Malang: GKKR, 2013), 426 .

44 Matalu, Dogmatika, 426.
} 


\section{Kovenan Kerja dan Istilah "Kovenan"}

Keberatan Hoekema terhadap doktrin kovenan kerja dalam poin ini adalah karena istilah "kovenan" tidak muncul secara eksplisit. Menurut penulis, pengusung doktrin kovenan kerja bukan mengabaikan ketidaktampakan istilah "kovenan" secara eksplisit. ${ }^{45}$ Bagi mereka, yang paling penting adalah apakah konsep atau elemen-elemen utama untuk membangun doktrin kovenan kerja ada atau tidak. Ketika konsep atau elemen-elemen itu ada, maka tidak ada dasar untuk tidak membangun doktrin kovenan kerja. Hodge memperlihatkan bahwa elemen-elemen utama untuk membangun doktrin kovenan kerja semuanya ada: dua pihak disebutkan, syarat ditentukan, ancaman hukuman dinyatakan, dan janji dikemukakan. ${ }^{46}$

Berkhof memberikan argumen yang sangat kuat terkait tidak munculnya istilah "kovenan" melalui membandingkan doktrin kovenan kerja dan doktrin Allah Tritunggal. Jikalau doktrin Allah Tritunggal bisa dibangun tanpa kemunculan istilah "Tritunggal" secara eksplisit, maka tidak ada alasan untuk tidak membangun

\footnotetext{
45 Jikalau dilihat secara sepintas, nampaknya penulis tidak konsisten dalam hal metode berargumentasi terkait relasi antara istilah dan konsep kovenan yang dikemukakan Lillback, Hoekema, Hodge dan Berkhof. Tetapi sebetulnya tidak demikian. Poin mereka adalah: Lillback, "Adanya istilah, signifikan bagi adanya konsep." Hoekema, "Tidak adanya istilah, signifikan bagi tidak adanya konsep." Hodge dan Berkhof, "Tidak adanya istilah, tidak signifikan bagi tidak adanya konsep." Menurut penulis, dalam hal ini, pernyataan Lillback tepat sedangkan pernyataan Hoekema tidak tepat. Sebab, ketika istilah muncul, pasti ada konsep yang menyertainya. Konsep melekat pada istilah, dan tidak ada istilah yang tidak memiliki makna. Akan tetapi, tidak munculnya istilah, tidak serta merta menjadikan konsep tidak ada. Sebab, sebagaimana yang dikemukakan Hodge dan Berkhof, meskipun secara istilah tidak ada, konsep kovenan tetap bisa ada melalui adanya elemen-elemen penunjang.

46 Hodge, Systematic Theology, 115-20.
} 
doktrin kovenan kerja hanya karena istilah "kovenan" tidak muncul secara eksplisit. ${ }^{47}$ Meredith Kline juga memberikan argumen yang tidak kalah pentingnya. Menurut Kline, istilah “kovenan kekal” yang dicatat dalam 2 Samuel 23:5 dan istilah “kovenan” yang ditemukan dalam Mazmur 89:4 merujuk kepada peristiwa yang terjadi di 2 Samuel 7. Di sini, kedua ayat tersebut sepakat untuk menyimpulkan bahwa relasi Tuhan Allah dengan Daud dalam 2 Samuel 7 adalah relasi kovenan, padahal istilah "kovenan"sama sekali tidak muncul. ${ }^{48}$ Berarti, meskipun secara istilah tidak ada, tetapi karena secara konsep ada, maka Alkitab sendiri menyebutnya sebagai kovenan.

Argumen-argumen di atas menjadi semakin kuat ketika istilah “kovenan" dalam Hosea 6:7, yang menurut penulis lebih berpihak kepada pendukung kovenan kerja, turut dipertimbangkan. Dalam


they were unfaithful to me there" (NIV). Bavinck berpendapat bahwa istilah כָזָד bukan mengacu kepada manusia pada umumnya tetapi secara khusus mengacu kepada Adam. Alasannya, secara gramatika Ibrani, jikalau terjemahan "like [the covenant] a man" yang dimaksud, maka seharusnya istilah בָָָּרָ ditempatkan sesudah kata בְרית dan bukan sesudah subjek kata depan = dalam כָזָד mengharuskan kita untuk

\footnotetext{
47 Berkhof, Systematic, 213.

48 Meredith G. Kline, Kingdom Prologue (tanpa penerbit, 1993), 10.

49 Herman Bavinck, Reformed Dogmatics: God and Creation (Grand Rapids: Baker Academic, 2009), 565.
} 
menerjemahkannya sebagai "like Adam".50 Page H. Kelley menunjukkan bahwa kata depan ₹ dalam bahasa Ibrani berarti "as, like, according to (plus other meanings)."51 Karena itu, dalam hal ini pandangan Berkhof selaras dengan Kelley.

Pandangan Bavinck dan Berkhof mengenai istilah פָזָדָם dalam Hosea 6:7 didukung oleh B.B. Warfield (1851-1921). Setelah melakukan penelitian secara historis tentang ayat ini, ia menyimpulkan: "We do not think we should err therefore, if we adopted the translation, 'like Adam.' But if we should err, we should err in a great and goodly company."52 Warfield mengatakan demikian karena di sepanjang sejarah, banyak sekali penafsir yang memilih terjemahan "like Adam". Ia memperlihatkan daftar para penafsir yang memilih terjemahan "like Adam" sebagai berikut:

Cyril of Alex, Jerome, Rashi, Abarbanel; Luther, Montanus, Castalio, Clarius, Tarnovius, Turrettine, Burmann, Braun, Brakel, Marck, De Moor, Witsius, Van Mastricht, Edwards (II. 457), Tingstadius, Mauger, Newcome, Rosenmüller, Hesselberg, Schröder, Ackermann, Preiswerk, Boothroyd, Stuck, Drake, Umbreit, Hitzig, Vilmar, Kurtz, Keil, Delitzsch (on Job xxxi. 33); Hofmann (Schriftbeweis), Pusey, Cowles, Wünsche, Oehler, Schmoller, McCurdy, Orelli, Given, Orr, A.A. Hodge, Bavinck, Vos, Knabenbauer. ${ }^{53}$

50 Berkhof, Systematic, 214.

51 Page H. Kelley, Biblical Hebrew: An Introductory Grammar (Grand Rapids: Eerdmans, 1992), 28.

52 B.B. Warfield, Selected Shorter Writings, Ed. John E. Meeter (Phillipsburg: P \& R, 1970), 129.

53 Warfield, Selected, 129. 


\section{Kovenan Kerja dan Sumpah Kovenan}

Salah satu alasan Hoekema menolak pengaturan Adamik sebagai kovenan kerja adalah karena di dalamnya tidak ada sumpah kovenan dan upacara pengesahan kovenan. Mengenai hal ini, penulis berpandangan bahwa tidak adanya sumpah kovenan dan upacara pengesahan kovenan tidak serta merta menjadikan pengaturan Adamik tidak bisa disebut sebagai kovenan. Dalam kajian penulis, argumen berikut tetap mendukung keberadaan doktrin kovenan kerja meskipun tanpa sumpah kovenan dan upacara pengesahannya. Hoekema sendiri mengonfirmasi penemuan para periset kovenan bahwa kovenan-kovenan dalam Perjanjian Lama yang disahkan dengan sumpah dimulai dalam Kejadian 15, yaitu dalam kovenan dengan Abraham. ${ }^{54}$ Dengan mengatakan demikian, maka secara implisit Hoekema mengakui bahwa dalam kovenan dengan Nuh juga tidak ada sumpah kovenan. Penulis berpendapat bahwa tidak ada seorang pun yang berani mengatakan bahwa Tuhan Allah tidak pernah mengadakan kovenan dengan Nuh. Karena itu, jikalau dalam konteks Nuh, kovenan tetap bisa dilangsungkan tanpa adanya sumpah kovenan, mengapa dalam kasus Adam hal yang sama tidak bisa berlaku?

Selain itu, perbedaan utama antara kovenan dengan Adam dan kovenan dengan Abraham serta kovenan-kovenan sesudahnya, yang menurut Hoekema dianggap sah karena ada sumpah kovenan, adalah bahwa yang pertama diadakan sebelum kejatuhan dan yang

54 Hoekema, Created, 120. 
kedua diadakan setelah kejatuhan. Sebelum kejatuhan, belum ada dosa. Karena itu, sumpah tidak diperlukan dalam mengikat kovenan. Sumpah diperlukan ketika ada kekhawatiran dari satu pihak bahwa pihak yang lainnya mungkin ingkar akan kewajiban kovenannya. Di samping itu, kebudayaan manusia pada zaman sebelum Adam jatuh ke dalam dosa belum berkembang. Karena itu, ritual atau upacara pengesahan kovenan juga belum diatur sedemikian rupa. Perlu diperhatikan bahwa kovenan bukan hanya ditemukan dalam Alkitab, tetapi juga muncul dalam kebudayaan-kebudayaan lain di daerah Timur Dekat Kuno. Jikalau yang sesungguhnya terjadi adalah bahwa konsep kovenan dalam Alkitab diadopsi dari kebudayaan di luar Alkitab, maka itu berarti Tuhan mengizinkan konsep kovenan dengan segala ritual yang menyertainya berkembang lebih dulu. Ketika sudah tiba waktunya, diadopsi dan ditebus untuk kemudian disesuaikan dengan konteks sejarah penebusan. Itu sebabnya, kovenan sesudah kejatuhan lebih kompleks, dan salah satu elemen di dalamnya adalah sumpah kovenan dan upacara pengesahannya.

\section{Kovenan Kerja dan Konteks Penebusan}

Hoekema mengatakan bahwa kovenan selalu dipakai dalam konteks penebusan. Ketika menjawab hal ini, Matalu mengatakan bahwa tentu saja demikian oleh karena sejak pasal ketiga Kitab Kejadian, dengan sangat dini sudah dinyatakan tentang kejatuhan dan juga mengenai rencana penebusan (Kejadian 3:15), dan sejak saat itu tema mengenai kovenan anugerah menjadi sentral. Tetapi hal ini 
tidak berarti bahwa istilah "kovenan" hanya boleh digunakan dalam konteks penebusan. ${ }^{55}$

\section{Implikasi Doktrin Kovenan Kerja}

Dari hasil peninjauan terhadap argumen-argumen penentang doktrin kovenan kerja, ditemukan bahwa posisi mereka ternyata tidak cukup kuat untuk dipertahankan. Karena itu, tidak ada alasan bagi kita untuk tidak menerima doktrin kovenan kerja. Hal ini memimpin kita untuk melangkah lebih jauh, meninjau dua implikasi doktrinal yang ada sebagai hasil dari penerimaan atas doktrin kovenan kerja, yaitu permasalahan mengenai transmisi dosa dan ketidakberdosaan Kristus.

\section{Kovenan Kerja dan Transmisi Dosa}

Dalam teologi Reformed, ada dua pandangan utama yang muncul ketika membahas doktrin transmisi dosa, yaitu teori realistik dan teori imputasi langsung. ${ }^{56}$ Teori realistik mengatakan bahwa Allah pada mulanya menciptakan natur manusia generik, yang dalam perjalanan waktu terbagi menjadi banyak individu yang terpisah-pisah. Adam memiliki keseluruhan natur manusia ini. Manusia individual bukanlah substansi-substansi yang terpisah, tetapi merupakan manifestasi dari substansi umum yang sama;

\footnotetext{
55 Matalu, Dogmatika, 430.

56 Di kalangan Reformed, teori realistik antara lain dianut oleh Augustinus, William G.T. Shedd, Augustus H. Strong, S. Greijdanus, dan K. Schilder. Sedangkan teori imputasi langsung dianut oleh Hodge, Bavinck, J. Gresham Machen, A.D.R. Polman, Murray, dan Berkhof.
} 
secara numerik mereka satu. Itu sebabnya, ketika Alkitab mengatakan bahwa manusia berdosa karena dosa Adam, maka dalam satu pengertian, dosa itu merupakan dosa aktual seluruh umat manusia. Tetapi bagaimana semua manusia bisa berdosa secara aktual padahal ketika Adam melakukan dosa pertama, mereka belum ada? Jawaban bagi pertanyaan ini adalah karena ketika Adam melakukan dosa pertama, semua manusia berada dalam buah pinggang Adam. Dasarnya adalah Ibrani 7:9-10 yang berbicara mengenai Lewi yang ikut memberikan perpuluhan kepada Melkisedek melalui Abraham, karena ketika Abraham memberikan perpuluhan, ia berada dalam buah pinggang Abraham. ${ }^{57}$

Akan tetapi, paling tidak ada dua kesulitan utama yang muncul ketika menerima teori ini. Pertama, teori ini tidak bisa menjelaskan mengapa hanya dosa pertama Adam yang ditangggung oleh keturunannya, dan bukan dosa-dosa yang ia lakukan sesudah dosa yang pertama itu. Kedua, berdasarkan teori ini, Kristus pasti berbagian di dalam natur manusia yang sama, natur yang secara aktual berdosa di dalam Adam. Tetapi mengapa Kristus tidak mewarisi dosa asal?58 Dalam analisis penulis, satu-satunya jalan keluar bagi dua kesulitan ini hanya didapatkan dalam teori imputasi langsung, yang dibangun berdasarkan kerangka doktrin kovenan kerja. ${ }^{59}$ Teori imputasi langsung mengajarkan bahwa Adam memiliki

\footnotetext{
57 Bdk. Berkhof, Systematic, 241. Hoekema, Created, 157-60.

58 Bdk. Berkhof, Systematic, 241-2.

59 Permasalahan mengenai Kristus yang tidak berbagian dalam dosa asal akan penulis bahas dalam poin "Kovenan Kerja dan Ketidakberdosaan Kristus."
} 
hubungan ganda dengan keturunannya, yaitu hubungan alamiah dan hubungan kovenan. Dalam hubungan alamiah, Adam adalah bapa dari seluruh umat manusia. Ketika ia berdosa, maka ia mengalami kecemaran dan karenanya ia akan dihukum. Dalam pengertian hubungan alamiah, dosa ini hanya ditanggung sendiri oleh Adam dan tidak diperhitungkan kepada keturunannya. Kalau demikian, mengapa dikatakan bahwa umat manusia berbagian dalam dosa Adam? Jawaban bagi pertanyaan ini ditemukan dalam hubungan yang kedua, yaitu hubungan kovenan. Dalam hubungan kovenan, Allah menentukan bahwa Adam tidak boleh berdiri sebagai dirinya sendiri saja, tetapi sebagai wakil dari semua keturunannya. Ketika ia berdosa, ia berdosa sebagai wakil umat manusia, sehingga semua manusia tercakup di dalam kesalahan akibat dosa tersebut dan di dalam penghukuman yang merupakan akibatnya. Dosa Adam diimputasikan secara langsung kepada semua keturunannya. ${ }^{60}$

Melalui terang teori imputasi langsung ini, pertanyaan mengenai mengapa hanya dosa pertama Adam yang ditanggungkan kepada keturunannya mendapatkan jalan keluar. Matalu mengatakan, Adam adalah wakil umat manusia yang berdiri di hadapan Tuhan dalam kovenan kerja. Jabatan dan fungsinya sebagai wakil umat manusia hanya bisa berlangsung jika ia taat secara terusmenerus sampai lulus dalam ujian ketaatan tersebut. Maka ketika ia jatuh, secara otomatis jabatan dan fungsinya sebagai wakil umat manusia gugur dengan sendirinya. Itu sebabnya, dosa-dosa Adam

\footnotetext{
60 Bdk. Berkhof, Systematic, 241.
} 
setelah kejatuhan tidak diwariskan kepada keturunannya karena semuanya itu dilakukan ketika ia tidak lagi menjadi wakil. ${ }^{61}$ Dengan demikian, bagi penulis, seseorang yang menolak doktrin kovenan kerja tidak akan mendapatkan solusi terkait permasalahan transmisi dosa.

\section{Kovenan Kerja dan Ketidakberdosaan Kristus}

Di sepanjang sejarah, teologi Reformed berpegang pada pengakuan bahwa Kristus adalah satu Pribadi dengan dua natur; Pribadi Allah (Logos), dan natur Allah dan natur Manusia. Pembahasan mengenai satu Pribadi Kristus dengan dua natur pada saat inkarnasi merupakan doktrin yang sangat rumit. Dengan tepat Berkhof mengatakan, "It [the Church] has always recognized the incarnation as a mystery which defies explanation. And so it will remain, because it is the miracle of miracles." 62 Meskipun demikian, Gereja tetap berusaha menjelaskan misteri yang rumit ini, tetapi dengan selalu berpegang pada satu prinsip penting bahwa Alkitab memberitahu kita seperti apa Kristus itu tanpa adanya usaha untuk menunjukkan bagaimana Ia menjadi seperti demikian. ${ }^{63}$ Karena itu, pertama-tama penulis akan menjelaskan definisi natur dan pribadi, dan menunjukkan kesulitan yang ada ketika melakukan pembedaan di antara keduanya. Setelah itu, penulis akan memperlihatkan

\footnotetext{
61 Matalu, Dogmatika, 457-8.

62 Berkhof, Systematic,321.

63 Berkhof, Systematic, 321.
} 
penjelasan resmi Gereja dan para teolog Reformed mengenai natur dan Pribadi Kristus. Terakhir, penulis akan menjelaskan kaitan antara kovenan kerja dan ketidakberdosaan Kristus.

Menurut Berkhof, istilah "natur" menunjuk kepada keseluruhan kualitas esensial dari sesuatu, yang menjadikan sesuatu itu sebagaimana adanya. Sebuah natur adalah suatu substansi yang dimiliki secara umum, dengan semua kualitas esensial dari substansi itu. ${ }^{64}$ Berdasarkan definisi ini, penulis menyimpulkan bahwa jikalau sesuatu ini kehilangan kualitas esensialnya, maka ia tidak bisa lagi disebut sebagai sesuatu. Dengan demikian, dalam penafsiran penulis, "kualitas esensial dari sesuatu" yang dimaksud Berkhof setara dengan "properti esensial dari suatu objek" dalam pengertian Ronald H. Nash. ${ }^{65}$ Menurut Nash, properti esensial adalah properti yang tidak dapat diubah atau hilang tanpa meniadakan objek yang bersangkutan dari jenisnya sekarang. ${ }^{66}$ Karena itu, untuk memudahkan kita memahami definisi Berkhof tentang natur, penulis meminjam contoh yang dikemukakan Nash mengenai sebuah bola berwarna merah. Warna merah adalah properti non-esensial dari bola tersebut. ${ }^{67}$ Ketika warna merah diganti dengan warna pink, bola itu tetap disebut bola. Sementara itu, bulat adalah properti esensial atau kualitas esensial dari bola tersebut. Ketika bulatnya dihilangkan, bola

\footnotetext{
64 Ibid., 321.

65 Ronald H. Nash, Konflik Wawasan Dunia, terj. Irwan Tjulianto (Surabaya: Momentum, 2008), 138-9.

66 Nash, Konflik,138-9.

67 Di sini Nash tidak memberikan definisi mengenai apa itu properti non-esensial.
} 
menjadi non-bola. Di sini, poin yang penulis mau katakan adalah bahwa natur merupakan sesuatu yang melekat pada objek.

Selanjutnya, Berkhof mengatakan, istilah "pribadi" menunjuk pada substansi yang lengkap yang diperlengkapi dengan pikiran, dan karenanya bertanggung jawab atas tindakan-tindakannya sendiri. Kepribadian bukanlah suatu bagian esensial dan integral dari suatu natur, akan tetapi sebagaimana adanya dulu, merupakan terminal akhir dari kecenderungannya. Suatu pribadi adalah sebuah natur dengan sesuatu yang ditambahkan, suatu subsistensi yang independen, yaitu individualitas. ${ }^{68}$ Definisi Berkhof bahwa pribadi adalah natur yang diperlengkapi dengan pikiran dan karenanya pribadi tidak melekat pada objek, jelas merupakan definisi yang kurang memadai dan membingungkan. Bagi penulis, pikiran adalah kualitas esensial dari sebuah natur dan karenanya melekat pada natur.

Sampai di sini, satu hal yang dapat disimpulkan adalah bahwa usaha untuk membedakan natur dan pribadi merupakan usaha yang sangat sulit. Karena kesulitan ini, Berkhof sendiri tidak konsisten dengan definisinya. Di bagian lain ia mengatakan bahwa kesadaran dan kehendak bebas adalah milik natur dan bukan milik pribadi. ${ }^{69}$ Seharusnya, kalau ia konsisten dengan definisinya mengenai pribadi,

\footnotetext{
68 Berkhof, Systematic, 321. Di sini ada penggunaan yang tumpang tindih antara subsistensi dan pribadi. Sebetulnya, istilah "subsistensi" setara dengan "pribadi", juga setara dengan hypostasis dalam bahasa Yunani dan persona dalam bahasa Latin. Lihat Gerald Bray, God is Love: A Biblical and Systematic Theology (Wheaton: Crossway, 2012), 120.

69 Berkhof, Systematic, 322.
} 
maka kesadaran dan kehendak bebas adalah milik pribadi dan bukan milik natur. Sebab kesadaran dan kehendak timbul sebagai akibat dari aktivitas pikiran. Tetapi di sini penulis sekadar mengkritisi pandangan Berkhof, dan tidak sedang berusaha untuk melangkah lebih jauh dengan menyatakan posisi yang berseberangan dengannya. Pertama-tama, karena konteks pembicaraan Berkhof adalah konteks Kristologis. Ada kesulitan-kesulitan Kristologis yang ingin dihindari sehingga ia mengatakan bahwa kesadaran dan kehendak bebas adalah milik natur. Di samping itu, karena konteks historis. Robert Letham mengatakan, secara historis, gereja telah menyatakan bahwa kehendak Kristus adalah properti dari naturnatur, bukan properti dari pribadi. Dengan demikian, dalam hal ini Letham sejalan dengan Berkhof.

Tetapi apakah karena kesulitan ini, pembedaan antara natur dan pribadi perlu ditiadakan sehingga natur boleh disamakan dengan pribadi? Jawaban bagi pertanyaan ini adalah tidak. Salah satu alasannya adalah karena konsili Chalcedon (451) sendiri melakukan pembedaan secara eksplisit antara natur dan Pribadi Kristus. Memang konsili Chalcedon tidak inerrant, tetapi bagaimanapun, pembedaan yang sudah dilakukan ini telah diterima sebagai rumusan standar Kristologi, dan konsili Chalcedon sendiri adalah konsili yang otoritatif di sepanjang sejarah gereja. Karena itu, di sini penulis mengambil dua kesimpulan. Pertama, meskipun mengandung kesulitan, penulis tetap mengikuti definisi dan pembagian yang dilakukan Berkhof mengenai natur dan pribadi, 
yaitu bahwa natur adalah sesuatu yang melekat pada objek, sedangkan pribadi adalah natur yang ditambahkan dengan sesuatu, sehingga pribadi tidak dengan sendirinya melekat pada objek. Kedua, berdasarkan definisi dan pembagian ini, dalam konteks natur dan pribadi manusia, keduanya dapat dibedakan tetapi tidak dapat dipisahkan. Manusia menjadi manusia yang utuh ketika di dalamnya ada kesatuan antara natur dan pribadi. Itu sebabnya, dalam hal pengimputasian dosa Adam, penulis berpendapat bahwa pengimputasian ini mencakup natur dan pribadi.

Selanjutnya penulis akan beralih kepada penjelasan mengenai natur dan Pribadi Kristus. Rumusan standar gereja bagi hubungan antara dua natur Kristus dinyatakan secara negatif oleh konsili Chalcedon: Kristus dikenal dalam dua natur, tidak terbagi, tidak terpisah, tidak bercampur, dan tidak berubah. Perbedaan kedua natur sama sekali tidak disingkirkan oleh kesatuan kedua natur itu, tetapi sifat masing-masing natur tetap dipertahankan dan ada bersamasama dalam satu Pribadi dan satu Subsistensi, tidak saling terpisah atau terbagi menjadi dua Pribadi. ${ }^{70}$ Berkhof berpandangan bahwa rumusan ini dinyatakan secara negatif, terutama sebagai suatu usaha untuk menjaga kebenaran ini dari berbagai macam pandangan sesat yang berusaha menyerang. ${ }^{71}$ Karena itu, dapat dikatakan bahwa setiap penyimpangan terhadap Kristologi terkait dua natur Kristus,

70 Berkhof, Systematic, 322.

71 Ibid. 
merupakan penyimpangan terhadap rumusan Chalcedon. ${ }^{72}$ Apollinaris (310-390) mengatakan bahwa Yesus adalah Allah yang mengambil tubuh dan jiwa manusia tetapi "Aku" Manusia Yesus sepenuhnya diambil dari Logos. Di sini Apollinaris mengorbankan kemanusiaan Yesus, dalam pengertian bahwa kemanusiaan-Nya terhisap dalam ke-Allahan-Nya. Karena itu, ia melanggar prinsip "tidak bercampur" dan "tidak berubah". Nestorius (428-431) mengajarkan bahwa ada dua pribadi yang saling melekat satu dengan yang lainnya, yakni pribadi Logos dan pribadi Manusia Yesus. Tidak ada kesatuan hakikat di antara keduanya, tetapi hanya ada kesatuan kehendak. Pandangan ini melawan prinsip "tidak terbagi" dan "tidak terpisah". Cyrillus (378-444) mengajarkan kesatuan dua natur Kristus, tetapi menganggap bahwa natur Manusia Kristus terhisap dalam keilahian-Nya. Pandangan ini melawan prinsip "tidak bercampur" dan "tidak berubah". Eutyches (380-456) mengatakan bahwa kemanusiaan Kristus dihisap oleh ke-Allahan-Nya, sehingga kemanusiaan-Nya hanya menyerupai kemanusiaan kita. Ajaran ini disebut monophysit dan dinyatakan sebagai bidat karena jelas-jelas mengabaikan dwi-natur Kristus dalam rumusan Chalcedon. ${ }^{73}$

Dua natur Kristus ini bersatu dalam satu Pribadi yaitu Pribadi Logos. Persatuan kedua natur tidak terjadi melalui percampuran antara keduanya, tetapi melalui kesatuan Pribadi-Nya. ${ }^{74}$ Penjelasan

\footnotetext{
72 Matalu, Dogmatika, 493.

73 Ibid., 493-4.

74 Ibid., 504.
} 
ini sejalan dengan pandangan Calvin yang mengatakan, "He who was the Son of God became the Son of Man, not by confusing of substance, but by unity of person." 75 Dari aspek kedua natur-Nya, persatuan kedua natur Kristus dalam satu Pribadi Logos tidak menghilangkan salah satu atau mencampurkan kedua natur tersebut, tetapi masing-masing natur tetap mempertahankan identitasnya secara sempurna. Dari aspek Pribadi, Pribadi Logos tidak mengalami perubahan apa-apa saat mengambil natur manusia. Yang terjadi adalah, setelah natur manusia diambil, Pribadi Logos menjadi Pribadi yang kompleks; Pribadi Allah-Manusia (Theanthropic Person). ${ }^{76}$

Oleh karena masing-masing natur mempertahankan identitasnya, boleh dikatakan bahwa Kristus memiliki dua roh (Allah dan Manusia), dua pikiran, dua emosi, dua kehendak, dan dua kesadaran. ${ }^{77}$ Letham menambahkan bahwa Kristus memiliki dua kehendak, satu kehendak ilahi dan satu kehendak manusiawi (dyotheletisme). Pandangan ini berlawanan dengan opsi satu kehendak (monotheletisme) yang telah ditolak gereja karena dipandang menutupi kemanusiaan Kristus. ${ }^{78}$ Jika semuanya ini adalah ciri dari suatu pribadi, maka kesimpulannya adalah bahwa Kristus yang memiliki dua pikiran, dua emosi, dua kehendak, dan dua kesadaran,

\footnotetext{
75 John Calvin, Institutes of the Christian Religion, ed. John T. McNeill, terj. Ford Lewis Battles (Philadelphia: Westminster Press, 1960), II.xiv.1.

76 Matalu, Dogmatika, 504.

77 Ibid., 505-6.

78 Robert Letham, Union with Christ: In Scripture, History, and Theology (Phillipsburg: P\&R, 2011), 414.
} 
seharusnya memiliki dua pribadi. Tetapi faktanya tidak demikian. Kristus hanya satu Pribadi. Karena itu, jawaban yang paling mungkin untuk kesulitan ini adalah bahwa kemanusiaan Kristus yang memiliki pikiran, emosi, kehendak, dan kesadaran sebagai manusia, tidak membentuk pribadi manusia sendiri, tetapi dengan sengaja seluruh hal yang seharusnya merupakan milik pribadi manusia, bermuara kepada Pribadi Logos. Hal ini tidak berarti bahwa kemanusiaan Kristus tidak berpribadi (impersonal). Tetapi bahwa kemanusiaan Kristus mengambil bagian pribadi-Nya dalam Pribadi Logos. Atau lebih tepatnya, Pribadi Logos mengambil kemanusiaan Kristus untuk berbagian dalam Pribadi-Nya. Jadi, kemanusiaan Kristus berada di dalam Pribadi (in-personal) $\operatorname{Logos}^{79}$

Berdasarkan penjelasan di atas, sekarang penulis akan menjelaskan ketidakberdosaan Kristus dalam terang doktrin kovenan kerja. Di atas penulis sudah mengatakan bahwa pengimputasian dosa Adam mencakup natur dan pribadi. Dari aspek natur, natur kemanusiaan Kristus terdiri dari tubuh dan jiwa. Berkenaan dengan tubuh, apakah tubuh Kristus yang adalah darah dan daging Maria tidak mengalami pencemaran karena dosa Maria? Benar bahwa tubuh Kristus berasal dari darah dan daging Maria, tetapi janin Kristus secara otomatis disucikan oleh Roh Kudus dari kecemaran dosa Maria saat terjadi pembuahan dalam rahim. Istilah "dikandung dari Roh Kudus" dalam Pengakuan Iman Rasuli (bdk. Matius 1:20; Lukas 1:35) menunjukkan bahwa terjadinya natur manusia Yesus dan

79 Matalu, Dogmatika, 506-7. 
kelahiran-Nya melalui Maria adalah merupakan karya Roh Kudus. Dan penulis berpegang pada kredo bahwa segala sesuatu yang dikerjakan oleh Roh Kudus adalah kudus. Maka jelas bahwa tubuh manusia Yesus dalam rahim Maria sudah secara otomatis dikuduskan oleh Roh Kudus. Bagaimana dengan jiwa-Nya? Mengenai jiwa Kristus, penulis berpandangan bahwa jiwa diciptakan langsung oleh Tuhan saat terjadi pembuahan dalam rahim. Jadi, jiwa manusia Yesus tidak berasal dari Maria, dan oleh karenanya tidak berbagian dalam kecemaran jiwa Maria. Dari aspek pribadi, menurut doktrin kovenan kerja, pengimputasian dosa Adam tidak dikenakan kepada Kristus karena Ia bukan pribadi manusia tetapi Pribadi Logos. Dengan demikian Yesus tidak dapat diwakili oleh Adam. Adam hanya mewakili mereka yang merupakan pribadi-pribadi manusia. Berdasarkan argumen-argumen ini, dapat disimpulkan bahwa Kristus bebas dari dosa asal.

\section{Kesimpulan}

Dari apa yang sudah dibahas di atas, kita melihat bahwa Bullinger dan Calvin mengajarkan doktrin kovenan kerja. Dalam perjalanannya di kemudian hari, doktrin ini ditolak oleh teologteolog Reformed, seperti Murray, Berkouwer, dan Hoekema. Tetapi alasan yang mereka kemukakan tidak memiliki dasar Alkitab yang cukup. Keberatan mereka bahwa doktrin kovenan kerja mengabaikan elemen anugerah, tidak tepat. Penulis menunjukkan bahwa dalam relasi Tuhan Allah dengan manusia, elemen anugerah tidak pernah 
diabaikan. Demikian juga dengan alasan ketidaktampakan istilah "kovenan". Penulis memperlihatkan bahwa meskipun secara istilah tidak ada, tetapi secara konsep, doktrin kovenan kerja ada dalam Alkitab. Alasan bahwa tidak adanya sumpah kovenan dan bahwa kovenan selalu dalam konteks penebusan, juga sudah dijawab. Karena itu, tidak ada alasan bagi kita untuk tidak berdiri dalam garis yang sama dengan Bullinger dan Calvin yang telah berjuang merintis doktrin kovenan kerja, serta Hodge, Bavinck, dan Berkhof yang telah berjuang mempertahankan doktrin yang agung ini. Melaluinya, permasalahan mengenai transmisi dosa dan ketidakberdosaan Kristus mendapatkan penjelasan yang lebih memuaskan. 